\title{
Cranial neuropathy in COVID-19: a case series and review of literature
}

\author{
Niraj Bohania1, Pranav Ish ${ }^{2}$, Arvind Nune ${ }^{3}$, Karthikeyan P. Iyengar ${ }^{4}$ \\ ${ }^{1}$ Department of Medicine, RR Hospital and Research Centre, West Bengal; \\ 2Department of Pulmonary, Critical Care and Sleep Medicine, VMMC and Safdarjung Hospital, New Delhi, India; \\ ${ }^{3}$ Department of Rheumatology, Southport and Ormskirk Hospital NHS Trust, United Kingdom; \\ ${ }^{4}$ Department of Orthopaedics, Southport and Ormskirk NHS Trust, United Kingdom
}

Article received 20 August, 2021; accepted 16 October, 2021

\section{SUMMARY}

Neurological presentation of COVID-19 is increasingly being recognised. Cranial neuropathy in COVID-19 is an uncommon and under-diagnosed entity. We report a case series of 4 patients who presented with trigeminal neuropathy (two cases) and facial nerve palsy (two cases) which recovered with conservative treatment along with the review of the literature.

Keywords: COVID-19, trigeminal neuralgia, Bell's palsy.

\section{INTRODUCTION}

OVID-19 has spread as a pandemic geographically and has demonstrated multiple systemic manifestations beyond the respiratory system. Neurological manifestations including headache, stroke, seizures, Guillain-Barré Syndrome and Acute disseminated encephalomyelitis have been documented as clinical presentations of COVID-19 [1, 2]. However, rarely COVID-19 can also affect cranial nerves leading to varied and atypical presentations. These can lead to delayed recognition and appropriate therapy. We report a case series of 4 patients who presented with cranial neuropathies within 2 weeks of COVID-19 infection and showed complete recovery, along with a review of literature for the same.

Case 1: A 44-year-old male presented with a 2 days history of fever, generalized body ache and dry cough. Rapid antigen test (RAT) for COVID-19 was done and it came out to be positive. On ex-

$\overline{\text { Corresponding author }}$

Pranav Ish

E-mail: pranavish2512@gmail.com amination, the patient's blood pressure (BP) was $132 / 80 \mathrm{~mm} \mathrm{Hg}$, pulse rate (PR) $110 / \mathrm{min}$, respiratory rate (RR) $18 /$ minute and saturation oxygen (SPO2) $-98 \%$ on room air. Patient was managed as a case of mild infection as per Indian national guidelines with antipyretics and nutritional supplements with monitoring of vitals in home isolation. On day 5 of illness, the patient had residual mild cough which resolved by day 8-9. On day 11, he developed a paroxysmal, stabbing type of pain on the right side of face. Pain was aggravated by chewing \& laughing. On examination, the patient described pain in the mandibular and maxillary region of the trigeminal nerve (right side). Patient was started on Carbamazepine $200 \mathrm{mg}$ twice a day and was symptomatically better in five days. Patient became asymptomatic after one week and discontinued medications. On a follow up visit on day 17 of illness, there were no symptoms or any neural loss.

Case 2: A 32-year-old male presented with a 3 days history of cough, generalized body ache, diarrhoea and fever. On examination, the patient's $\mathrm{BP}$ was 118/70 mm Hg, PR 106/min, RR 17/min and SPO2-99\% on room air. Patient was advised to take a rapid antigen test for COVID-19 which 
came out to be positive. Patient was managed as a case of mild infection as per Indian national guidelines with antipyretics and nutritional supplements with monitoring of vitals in home isolation. Patient became asymptomatic on day 6 . On day 9, the patient developed pain on the right side of face which he described as a paroxysmal, lancinating type of pain which got aggravated on chewing \& touching. On examination, the patient described pain in the mandibular and partially in maxillary region of trigeminal nerve (right side). Patient was started on carbamazepine 200 mg twice a day, but he complained of increased sleepiness, so dose decreased to $100 \mathrm{mg}$, which subsequently was increased to $200 \mathrm{mg}$ bd after 3 days. On day 6 , the patient was symptomatically better but pain was still present, so dose increased to $200 \mathrm{mg}$ thrice a day. Patient presented after 2 weeks with resolution of symptoms, so dose was reduced to $100 \mathrm{mg}$ twice a day for one week, after which it was stopped.

Case 3: An 18-year-old female presented with a history of facial deviation toward the left side, inability to close right eye for 1 day. Patient also had a history of cough and generalized body ache 1 week back for which she got tested positive for COVID-19 antigen. On examination, the patient's BP was $110 / 72 \mathrm{~mm} \mathrm{Hg}$, PR 88/min, RR16/min and $\mathrm{SPO} 2-99 \%$ on room air. On neurological examination, there was lower motor neuron (LMN) type of right facial palsy and the rest of the examination was normal. Patient was started on steroids ( $1 \mathrm{mg} / \mathrm{kg}$ body weight), eye taping during sleep and methylcellulose eye drops. After 1 week, the patient improved significantly and steroids were tapered over the next 2 weeks. After 2 weeks, there was no residual focal neurological deficit.

Case 4: 20-year-old male presented with fever, cough and body ache for 3 days. On examination, the patient's BP was 128/80 mm Hg, PR 116/min, RR $17 / \mathrm{min}$ and SPO2-96\% on room air. Patient turned out to be COVID-19 polymerase chain reaction (PCR) positive. Patient was also managed as a case of mild infections. On day 11, the patient developed LMN type of facial palsy on the right side. Patient was started on steroids $(1 \mathrm{mg} / \mathrm{kg}$ body weight), methylcellulose eye drops and advised aye taping during sleep. After 5 days, the patient improved significantly and at 2 weeks, there was no residual focal neurological deficit.

\section{LITERATURE SEARCH AND REVIEW}

The search of PubMed for [[COVID-19] OR [SARS CoV2] $\}$ and $\{[$ Cranial neuropathy] OR [cranial nerve]\} revealed 221 results as on $9^{\text {th }}$ September 2021. After excluding review articles or letters or which did not have any patient data, cases which were post-COVID-19 recovered patients with tu-

Table 1 - Summary of published literature of cranial neuropathy during COVID-19.

\begin{tabular}{|c|c|c|c|c|}
\hline Article & Patients & Cranial neuropathy & Treatment & Outcome \\
\hline $\begin{array}{l}\text { Finsterer J } \\
\text { et al. [3] }\end{array}$ & $\begin{array}{l}\text { Systematic } \\
\text { review of } \\
36 \text { articles with } \\
56 \text { patients }\end{array}$ & $\begin{array}{l}\text { Single cranial nerve involved } \\
\text { in } 36 \text { patients, while in } 19 \\
\text { patients, multiple cranial } \\
\text { nerves were involved. } \\
\text { Bilateral involvement was } \\
\text { more in GBS group }\end{array}$ & $\begin{array}{l}\text { Steroids ( } n=18), \\
\text { intravenous } \\
\text { immunoglobulins (IVIG) } \\
(n=18) \text {, acyclovir/ } \\
\text { valacyclovir }(n=3), \\
\text { and plasma exchange } \\
(n=1)\end{array}$ & $\begin{array}{l}\text { The outcome } \\
\text { was classified as } \\
\text { "complete recovery" } \\
\text { in } 21 \text { patients and } \\
\text { as "partial recovery" } \\
\text { in } 30 \text { patients. } \\
\text { One patient had a } \\
\text { lethal outcome. }\end{array}$ \\
\hline \multicolumn{5}{|c|}{ Other studies not included in the above systematic review } \\
\hline $\begin{array}{l}\text { Tamaki } \\
\text { et al. [4] }\end{array}$ & $\begin{array}{l}\text { Cohort of } 348008 \\
\text { COVID-19 } \\
\text { patients from } \\
41 \text { centres }\end{array}$ & $\begin{array}{l}284(0.08 \%) \text { had Bell's palsy. } \\
131 \text { among these had a past } \\
\text { history of Bell's palsy }\end{array}$ & $\begin{array}{l}\text { Retrospective study with } \\
\text { no details regarding } \\
\text { treatment }\end{array}$ & $\begin{array}{l}\text { Retrospective study } \\
\text { with no details } \\
\text { regarding outcome }\end{array}$ \\
\hline $\begin{array}{l}\text { Piazza } \\
\text { et al. [5] }\end{array}$ & $\begin{array}{l}\text { Case report } \\
\text { of } 1 \text { patient }\end{array}$ & $\begin{array}{l}\text { Right sixth cranial nerve } \\
\text { palsy, CSF had high protein } \\
\text { and MRI had white matter } \\
\text { changes }\end{array}$ & $\begin{array}{l}\text { High-dose intravenous } \\
\text { methylprednisolone }\end{array}$ & $\begin{array}{l}\text { Rapid resolution } \\
\text { of clinical symptoms }\end{array}$ \\
\hline
\end{tabular}




\begin{tabular}{|c|c|c|c|c|}
\hline Article & Patients & Cranial neuropathy & Treatment & Outcome \\
\hline $\begin{array}{l}\text { Moyano A JR } \\
\text { et al. [6] }\end{array}$ & $\begin{array}{l}\text { Case report of } \\
\text { a } 38 \text {-year-old } \\
\text { female patient }\end{array}$ & $\begin{array}{l}\text { Vagus nerve neuropathy } \\
\text { presenting with dysphagia } \\
\text { and hypoesthesia in pharynx }\end{array}$ & $\begin{array}{l}\text { Multidisciplinary } \\
\text { rehabilitation program } \\
\text { that included speech and } \\
\text { deglutition therapy }\end{array}$ & Complete recovery \\
\hline $\begin{array}{l}\text { Francis } \\
\text { et al. [7] }\end{array}$ & $\begin{array}{l}\text { Case report } \\
\text { of a } 69 \text {-year-old } \\
\text { female patient }\end{array}$ & Left abducens nerve palsy & Rehabilitation & $\begin{array}{l}\text { Complete } \\
\text { spontaneous } \\
\text { recovery of the } \\
\text { abducens palsy } \\
\text { within } 6 \text { weeks }\end{array}$ \\
\hline $\begin{array}{l}\text { Gupta } \\
\text { et al. [8] }\end{array}$ & $\begin{array}{l}\text { Thirteen } \\
\text { articles (case } \\
\text { reports) from } \\
2020 \text { including } \\
20 \text { cases of } \\
\text { COVID-19 with } \\
\text { Bell's palsy }\end{array}$ & $\begin{array}{l}\text { Bell's palsy as the only major } \\
\text { neurological manifestation }\end{array}$ & Not mentioned & Not mentioned \\
\hline $\begin{array}{l}\text { Theophanous C } \\
\text { et al. [9] }\end{array}$ & $\begin{array}{l}\text { Case report of } \\
\text { a } 6 \text {-year-old child }\end{array}$ & Right sided facial palsy & $\begin{array}{l}\text { Intravenous acyclovir } \\
150 \text { mg every } 8 \text { hours, } \\
\text { scheduled dose of IVIG } \\
\text { infusion (for underlying } \\
\text { agammaglobulinemia). } \\
\text { Lubricating eye drops } \\
\text { for corneal protection }\end{array}$ & $\begin{array}{l}\text { The symptoms } \\
\text { improved at a } \\
\text { follow-up at } 3 \text { weeks }\end{array}$ \\
\hline $\begin{array}{l}\text { Halalau A } \\
\text { et al. [10] }\end{array}$ & $\begin{array}{l}\text { Case report } \\
\text { of a } 42 \text {-year-old } \\
\text { male patient }\end{array}$ & $\begin{array}{l}\text { Right vestibular } \\
\text { neuritis presented } \\
\text { with persistent vertigo, } \\
\text { persistent leftward } \\
\text { nystagmus and a positive } \\
\text { Romberg sign with a } \\
\text { tendency toward the right }\end{array}$ & $\begin{array}{l}\text { Oral prednisone } \\
\text { ( } 50 \mathrm{mg} \text { once daily } \\
\text { for } 5 \text { days) and meclizine } \\
\text { ( } 25 \mathrm{mg} \text { as-needed up } \\
\text { to thrice daily) }\end{array}$ & $\begin{array}{l}\text { Improvement } \\
\text { over } 2 \text { weeks }\end{array}$ \\
\hline $\begin{array}{l}\text { Kumar V } \\
\text { et al. [11] }\end{array}$ & $\begin{array}{l}\text { Case report } \\
\text { of a } 28 \text {-year-old } \\
\text { female patient }\end{array}$ & $\begin{array}{l}\text { Drooling from right sided } \\
\text { angle of mouth, deviation } \\
\text { of face to right and inability } \\
\text { to shut her right eye } \\
\text { suggestive of Right sided } \\
\text { facial nerve palsy }\end{array}$ & $\begin{array}{l}\text { Oral valacyclovir } 1 \mathrm{~g} \text { thrice } \\
\text { daily for } 10 \text { days and oral } \\
\text { prednisolone } 50 \mathrm{mg} \text { once } \\
\text { daily for } 7 \text { days followed } \\
\text { by tapered doses }\end{array}$ & $\begin{array}{l}\text { Improvement } \\
\text { at } 10 \text { days }\end{array}$ \\
\hline $\begin{array}{l}\text { Wei H } \\
\text { et al. [12] }\end{array}$ & $\begin{array}{l}\text { Case report } \\
\text { of a } 62 \text {-year-old } \\
\text { male patient }\end{array}$ & $\begin{array}{l}\text { Drooping of left eyelid } \\
\text { and diplopia. Left sided } \\
\text { oculomotor nerve palsy. } \\
\text { Respiratory failure with } \\
\text { SpO2 90\% }\end{array}$ & $\begin{array}{l}\text { Oxygen therapy, } \\
\text { moxifloxacin } 400 \mathrm{mg} \text {, } \\
\text { oseltamivir } 75 \mathrm{mg} \text {, } \\
\text { methylprednisolone } 40 \mathrm{mg} \\
\text { and ribavirin } 0.5 \mathrm{mg} \\
\text { once daily, lopinavir } \\
400 \mathrm{mg} \text { twice daily, } \\
\text { IVIg } 0.4 \mathrm{~g} / \mathrm{kg} \text { once daily, } \\
\text { paracetamol up to } 650 \mathrm{mg} \\
\text { thrice daily and ibuprofen } \\
600 \mathrm{mg} \text { twice daily } \\
\text { for } 12 \text { days }\end{array}$ & $\begin{array}{l}\text { Died on } 12^{\text {th }} \text { day } \\
\text { due to respiratory } \\
\text { failure }\end{array}$ \\
\hline $\begin{array}{l}\text { François J } \\
\text { et al. [13] }\end{array}$ & $\begin{array}{l}\text { Case report } \\
\text { of a woman } \\
\text { in her fifties }\end{array}$ & $\begin{array}{l}\text { Right eye optic neuritis } \\
\text { and uveitis with bilateral } \\
\text { pneumonia and temporal } \\
\text { arteritis }\end{array}$ & $\begin{array}{l}\text { Oral and topical } \\
\text { corticosteroids }\end{array}$ & $\begin{array}{l}\text { Regained partial } \\
\text { eyesight at } 45 \text { days }\end{array}$ \\
\hline
\end{tabular}

Notes: GBS, Guillain-Barré syndrome; IVIG, Intravenous immunoglobulin; Sp02, percent saturation of oxygen in the blood. 
berculosis, fungal sinusitis or other conditions leading to cranial nerve involvement, a total of 11 studies were enlisted (one systematic review and 10 other studies) in Table 1 [3-13]. It is evident from the literature that cranial neuropathy can occur across all age groups (6-year-old child to 62-year-old adult), can involve various cranial nerves $\left(2^{\text {nd }}, 3^{\text {rd }}, 5^{\text {th }}, 6^{\text {th }}, 7^{\text {th }}\right.$ and even $10^{\text {th }}$ cranial nerve), often requires no drug treatment resolving with only rehabilitation and conservative management, sometimes require steroids and rarely additional drugs like Intravenous immunoglobulin (IVIG). Mortality has been seen in two patients with $7^{\text {th }}$ nerve palsy, which was associated with Guillain-Barré syndrome (GBS) leading to respiratory failure [3, 12]. A large systematic review of 36 articles illustrates that facial nerve involvement is the most common manifestation reported among COVID-19 with cranial neuropathy, particularly more common in patients presenting with GBS [3].

\section{DISCUSSION}

Our case series comprised of young patients with mild COVID-19 with $5^{\text {th }}$ and $7^{\text {th }}$ cranial neuropathy which had a complete recovery similar to reported literature (Table 1). Partial recovery has occasionally been seen in optic and vestibular neuropathy. The two patients with facial nerve palsy in our series were treated with oral steroids. This is in contrast with the reported literature where most patients recovered spontaneously. However, steroid use has shown a rapid response in certain reported cases and moreover, even in post COVID-19 vaccination facial nerve palsy [14]. Our patients were being monitored with telemedicine and in view of rapid recovery, did not require prolonged course of steroids or gradual tapering of doses. The two patients with trigeminal neuralgia were treated with carbamazepine for 1 week and 3 weeks respectively. The use of carbamazepine may have been similar to placebo, but the second patient did report improvement of pain with the prolonged use. A recent case series reported rapid response with use of carbamazepine in four patients with COVID-19 who had recurrence of their underlying idiopathic trigeminal neuralgia [15].

In view of rapid and complete recovery with steroids, the possible pathophysiology of cranial neuropathy in COVID-19 may be immune-mediated.
However, direct entry of SARS CoV-2 into the trigeminal and facial nerve through ACE2 receptors of neuronal and glial cells is also a possibility [16]. The exact etiopathology can only be unravelled by large-scale studies and appropriate investigations. Unfortunately, all of our patients were in home isolation, and thus they could not undergo any neurological imaging or nerve conduction studies.

Anosmia and ageusia was also initially reported from few areas across the world leading to increased recognition and subsequent addition in the list of symptoms of COVID-19 [17]. Similarly, despite varied neurological manifestations ranging from central to peripheral nervous system in COVID-19, cranial nerve palsies are rare and possibly under recognised. Even as pulmonary specialists treat COVID-19, it is imperative to keep a multi-system approach while treating COVID-19. Unfortunately, non-pulmonary manifestations are not included in classifying such patients into moderate or severe cases in Indian guidelines. Eventually, all these patients with no hypoxia get classified as mild cases and are advised home isolation [18].

\section{CONCLUSIONS}

Thus, a high index of suspicion, close clinical follow-up and constant vigilance is necessary to timely diagnose these evolving neurological manifestations of COVID-19 as they are treatable and often show complete recovery [19]. Besides, in the peak COVID-19 waves, these symptoms should not be ignored as they may be the initial or the only manifestation of COVID-19.

\section{Financial support and sponsorship \\ None.}

\section{Conflicts of interest}

None.

\section{Consent}

Written informed consent was taken from the patients for sharing their clinical details in the article.

\section{Contributors}

PI and NB were involved in conceptualization, literature search. NB, PI, KPI and AN were involved in writing, review and editing. All authors have read and agreed to the final draft submitted. 


\section{REFERENCES}

[1] Brouwer MC, Ascione T, Pagliano P. Neurologic aspects of covid-19: a concise review. Infez Med. 2020; (Suppl. 1), 42-5.

[2] Sachdev K, Agrawal S, Ish P, et al. Neurological manifestations of COVID-19: A brief review. Indian J Med Res. 2020; 152, 41-7.

[3] Finsterer J, Scorza FA, Scorza C, Fiorini A. COVID-19 associated cranial nerve neuropathy: A systematic review. Bosn J Basic Med Sci. 2021; doi: 10.17305/ bjbms.2021.6341.

[4] Tamaki A, Cabrera CI, Li S, et al. Incidence of Bell Palsy in Patients With COVID-19. JAMA Otolaryngol Head Neck Surg. 2021; doi: 10.1001/jamaoto.2021.1266.

[5] Piazza F, Bozzali M, Morana G, et al. Early reversible leukoencephalopathy and unilateral sixth cranial nerve palsy in mild COVID-19 infection. Neurol Sci. 2021, 1-4. [6] Moyano A JR, Mejía Torres S, Espinosa J. Vagus nerve neuropathy related to SARS CoV-2 infection. IDCases. 2021; doi: 10.1016/j.idcr.2021.e01242.

[7] Francis JE. Abducens palsy and anosmia associated with COVID-19: A Case Report. Br Ir Orthopt J. 2021; 17 (1), 8-12.

[8] Gupta S, Jawanda MK, Taneja N, Taneja T. A systematic review of Bell's Palsy as the only major neurological manifestation in COVID-19 patients. J Clin Neurosci. 2021; 90, 284-92.

[9] Theophanous C, Santoro JD, Itani R. Bell's palsy in a pediatric patient with hyper IgM syndrome and severe acute respiratory syndrome coronavirus 2 (SARSCoV-2) Brain Dev. 2021; 43 (2), 357-9.

[10] Halalau A, Halalau M, Carpenter C, Abbas AE, Sims M. Vestibular neuritis caused by severe acute respiratory syndrome coronavirus 2 infection diagnosed by serology: Case report. SAGE Open Med Case Rep. 2021; doi: $10.1177 / 2050313 X 211013261$.

[11] Kumar V, Narayanan P, Shetty S, Mohammed AP. Lower motor neuron facial palsy in a postnatal mother with COVID-19. BMJ Case Rep. 2021; 14(3), e240267.

[12] Wei H, Yin H, Huang M, Guo Z. The 2019 novel coronavirus pneumonia with onset of oculomotor nerve palsy: a case study. J Neurol. 2020; 267 (5), 1550-3.

[13] François J, Collery AS, Hayek G, et al. Coronavirus Disease 2019-associated ocular neuropathy with panuveitis: a case report. JAMA Ophthalmol. 2021; 139 (2), 247-9.

[14] Ish S, Ish P. Facial nerve palsy after COVID-19 vaccination - A rare association or a coincidence. Indian J Ophthalmol. 2021; 69(9), 2550-2.

[15] Ricciardi L, Acqui M, Pucci R, et al. Transient Trigeminal Neuralgia Recurrence During Coronavirus disease-19 in Carbamazepine Responders Patients. J Craniofac Surg. 2021; doi: 10.1097/SCS.0000000000007893.

[16] Satarker S, Nampoothiri M. Involvement of the nervous system in COVID-19: The bell should toll in the brain. Life Sci. 2020; 262, 118568.

[17] Ish P, Sen MK, Gupta N. In Reference to Anosmia and Ageusia: Common Findings in COVID-19 Patients. Laryngoscope. 2020; 130 (9), E502.

[18] Clinical management protocol for covid-19. Government of India. Ministry of Health and Family Welfare. Downloaded from https://www.mohfw.gov.in/ pdf/UpdatedDetailedClinicalManagementProtocolforCOVID19adultsdated24052021.pdf. [Last accessed 8 July 2021].

[19] Ish P, Sachdev K, Agrawal S, Gupta N. Neurological manifestations of COVID-19 - continually evolving and perplexing. Ann Indian Acad Neurol. 2020; 23 (3), 361-2. 